\title{
Quantitation of Chlamydia trachomatis by culture, direct immunofluorescence and competitive polymerase chain reaction
}

\author{
E H Frost, S Deslandes, D Bourgaux-Ramoisy, P Bourgaux
}

\begin{abstract}
Objectives-Methods to quantitate Chlamydia trachomatis have never been compared although it would be relevant to periodically evaluate the sensitivity of a detection system. We compared the sensitivity and reproducibility of culture, direct immunofluorescence and the polymerase chain reaction (PCR) to quantitate $C$ trachomatis.

Methods-A competitive semiquantitative PCR procedure was developed. The number of inclusions in culture, particles by direct immunofluorescence and DNA copies by PCR were measured for 12 patient specimens. Variation was determined by measuring a sample 10 times for each method.

Results-Patient C trachomatis major outer membrane protein gene DNA was measured semiquantitatively by amplifying together with reference DNA. DNA molecules, particles and infectious units were quantitated in clinical samples with, on average, 595 DNA molecules and 87 immunofluorescent particles observed per inclusion-forming-unit. Similar coefficients of variation (47-52\%) were observed for the 3 procedures.

Conclusion-Competitive PCR and counting immunofluorescent particles provide reproducible and sensitive methods of quantitating $C$ trachomatis.
\end{abstract}

(Genitourin Med 1995;71:239-243)

Keywords: Chlamydia trachomatis; PCR; Immunofluorescence

\section{Introduction}

Chlamydia trachomatis has been recognised in the last two decades as a major world health problem not only as the causative agent of trachoma but also as the second most common sexually transmitted disease pathogen and an often insidious cause of infertility and ectopic pregnancy. Despite an explosion in the number and variety of chlamydial antigen and nucleic acid detection procedures, the long and labour-intensive culture procedure for $C$ trachomatis remains a "gold" standard for diagnosis largely because of its specificity. The sensitivity of culture for this bacterium, however, is variable and depends on a number of factors relating to the fragility of $C \mathrm{tra}$ chomatis, the variable potential of an elemen- tary body to initiate formation of an inclusion as well as the variability of cell culture systems. ${ }^{1-3}$ Indeed culture probably detects only $50-85 \%$ of the chlamydial infections that can be detected by the most sensitive polymerase chain reaction (PCR) or ligase chain reaction $^{4-10}$ including commercially-available kits. $^{8-10}$ At present, there is no recognised method to quantitate chlamydia and thus measure sensitivity directly although counting inclusions in culture or elementary bodies by direct immunofluorescence have been employed to provide an approximation. An ingenious method has been devised to use PCR to quantitate DNA copies by mixing known amounts of a modified template with the sample to be titrated, performing PCR and evaluating the relative amounts of DNA amplified from the modified template and sample. ${ }^{112}$ We have used this quantitation scheme and immunofluorescent particle counts to titrate $C$ trachomatis in order to evaluate the sensitivity of our culture procedure.

\section{Materials and methods \\ Culture of $C$ trachomatis}

$C$ trachomatis was cultured from cervical samples taken with a Zelsmyr Cytobrush (International Cytobrush, Hollywood, FA) or urethral samples using a PN/UR (Prolabs, Richmond Hill, Ontario) cotton-tipped, aluminium swab. The swab or cytobrush tip was cut off into 2SP medium and sent, on ice, to the laboratory where it was frozen at $-70^{\circ} \mathrm{C}$ prior to inoculation of $0.3 \mathrm{ml}$ aliquots by centrifugation at $2,000 \mathrm{~g}$ for $1 \mathrm{~h}$ onto coverslips in shell vials that had been seeded three days previously with McCoy (Ortho, Markham, Ontario) cells. After three days in medium containing $1 \mu \mathrm{g} / \mathrm{ml}$ of cycloheximide, inclusions were revealed by immunoperoxidase (Ortho or Bartels, Bellevue, WA) staining. A low and a high inclusion count positive control were included every time centrifugationassisted infection was performed. The low inclusion count specimen was concocted by diluting tenfold in 2SP a pool of several clinical specimens that had given over 100 inclusions and freezing $0.3 \mathrm{ml}$ aliquots at $-70^{\circ} \mathrm{C}$. These identical aliquots revealed 10 to 70 inclusions when cultured.

\section{$P C R$ sample extraction procedure}

Initially, chlamydial DNA for PCR amplification was extracted from residual 2 SP medium by mixing with an equal volume of $2 \mathrm{mM}$ $\mathrm{NaOH}$ and centrifuging at $14,000 \mathrm{rpm}$ for 5 
$\min$ in a microfuge. The pellet was resuspended in $10 \mu \mathrm{l}$ of $1 \mathrm{mM} \mathrm{NaOH}$ and heated at $80^{\circ} \mathrm{C}$ for $10 \mathrm{~min}$. Subsequently equal volumes of clinical sample and lysis buffer $(0.32$ $M$ sucrose, $10 \mathrm{mM}$ TRIS $\mathrm{HCl}(\mathrm{pH} \mathrm{7 \cdot 5}), 5$ $\mathrm{m} M \mathrm{MgCl}_{2}, 1 \%$ Triton $\mathrm{X}-100$ ) were mixed and microfuged $5 \mathrm{~min}$ at $14,000 \mathrm{rpm}$. The pellet was resuspended in $5 \mu \mathrm{l}$ of PCR buffer (Amersham, Oakville, Ontario) and $0.5 \mu \mathrm{l}$ each of $5 \%$ nonidet P-40, $5 \%$ Tween 20 and proteinase $K(1 \mathrm{mg} / \mathrm{ml})$ and incubated for $1 \mathrm{~h}$ at $56^{\circ} \mathrm{C}$, then for $10 \mathrm{~min}$ at $95^{\circ} \mathrm{C}$.

\section{Primers for PCR}

Primers are named by the position of the $5^{\prime}$ nucleotide sequence of the major outer membrane protein (MOMP) gene of the serovar $\mathrm{C}^{13}$ considering as position 1 the start of the leader sequence. Opposite strand primers are identified by an $R$. The nested pair of PCR primers $001,1077 R, 076$ and 1055R have already been described as primers $1,2,3$, and 4 , with the $3^{\prime}$ nucleotides at positions 22 , 1048, 95 and 1027 respectively. ${ }^{7}$ They were synthesised on a Pharmacia Gene Assembler by the Laboratory of Molecular Biology (Faculty of Medicine, University of Sherbrooke).

\section{Modified DNA standard}

The modified DNA standard necessary for competitive PCR was constructed from $C$ trachomatis serovar $\mathrm{L}_{2}$ DNA amplified by primers 001 and $1077 \mathrm{R}$ by digestion with the restriction endonuclease HhaI, which cleaves the L2 MOMP gene at nucleotides 628, 640 and 1006. The two fragments carrying homology to the primers (nucleotides 1 to 628 and 1007 to 1077) were ligated together with T4 DNA ligase (Pharmacia, Montreal, Québec) and then amplified using primer 001 and primer $1077 \mathrm{R}^{7}$ The resulting product, truncated by $378 \mathrm{bp}$, was quantitated as follows: a fulllength $C$ trachomatis PCR product was quantitated by ethidium bromide staining ${ }^{14}$ and then used in four independent experiments to quantitate the modified standard by competitive PCR (see below). Three of the four experiments indicated the same number of DNA copies and this value was used in subsequent experiments. The fourth experiment indicated a copy number two times higher. The consensus value was confirmed in a threefold dilution series. Three copies were always detected by nested PCR whereas only two of the four tests with one copy and none of three tests with 0.33 copies were positive.

\section{Competitive PCR}

Competitive PCR was performed by setting up four identical sample amplification reactions with a 10 (for samples with less than 10 inclusions), 100 (for samples with 25-50 inclusions) or 1000 (for samples with over 100 inclusions) fold dilution of sample to which were added $0,10,100$ or 1000 copies of the modified DNA standard. PCR cycling was undertaken with $5 \mu \mathrm{l}$ aliquots of sample in $50 \mu \mathrm{l}$ of PCR buffer (Amersham), including 1.25 units of hot tub polymerase
(Amersham), $200 \mu \mathrm{M}$ dNTP (Pharmacia) and $1 \mu \mathrm{M}$ primers. Reaction mixtures were submitted to 5 cycles of denaturation for 1 min at $94^{\circ} \mathrm{C}$, reannealing for $5 \mathrm{~min}$ at $55^{\circ} \mathrm{C}$ and elongation for $3 \mathrm{~min}$ at $72^{\circ} \mathrm{C}$ followed by 35 cycles of denaturation for $1 \mathrm{~min}$, reannealing for $1 \mathrm{~min}$ and elongation for $2 \mathrm{~min}$. In the final step elongation was for $10 \mathrm{~min}$. A $1 \mu \mathrm{l}$ sample was subjected to 30 cycles of PCR (1 min denaturation, $1 \mathrm{~min}$ reannealing, $2 \mathrm{~min}$ elongation with a final step of $10 \mathrm{~min}$ elongation) using the nested primer pair. Ten $\mu$ l of amplified product were analysed on agarose gels and stained with ethidium bromide (fig 1). The truncated control DNA migrated more rapidly than the sample DNA and could be readily distinguished. Visual inspection allowed determination of an approximate amount of sample DNA in comparison with the standard.

\section{Quantitation by counting particles stained by direct immunofluorescence}

Aliquots $(10$ and $100 \mu \mathrm{l})$ of residual patient sample in $2 \mathrm{SP}$ were pelleted for $1 \mathrm{~min}$ in a microfuge, resuspended in $10 \mu \mathrm{l}$ of distilled water and spotted in separate wells of a 10 well slide for immunofluorescence (Fisher, Toronto, Canada). After air drying and fixing with methanol for $10 \mathrm{~min}, 20 \mu \mathrm{l}$ of fluorescein-conjugated, monoclonal antibody to $C$ trachomatis (MicroTrak, Syva, Ottawa, Canada) was applied to each well. After 15 min incubation at room temperature, the slide was rinsed with distilled water, dried, mounted with a coverslip and observed at $1000 \times$ with a Leitz Diaplan microscope in order to count immunofluorescent $C$ trachomatis particles. Wells containing 40 to 500 immunofluorescent particles were counted.

\section{Statistical analysis}

The same sample was evaluated separately 10 times. The standard deviation was calculated and then divided by the mean in order to obtain the coefficient of variation. ${ }^{15}$

\section{Results}

Development of competitive PCR procedure

The competitive PCR procedure was based on the nested PCR protocol we have employed to detect and type $C$ trachomatis in urogenital ${ }^{716}$ and ocular samples. ${ }^{17}$ The truncated positive control used in these studies was quantitated and employed as a modified DNA standard for quantitation experiments (fig 1).

Initial quantitation studies employing the simple alkali DNA extraction procedure used previously in detection studies were conducted on clinical samples that had revealed fewer than 25 inclusions in culture, between 26 and 100, or more than 100 (see fig 2). A few samples were also available that had proven negative by culture but positive by PCR. The 38 clinical samples tested that had given more than 100 inclusions (per $0.3 \mathrm{ml}$ ) in culture revealed an average of $1.7 \times 10^{6}$ DNA copies by quantitative PCR, those with 


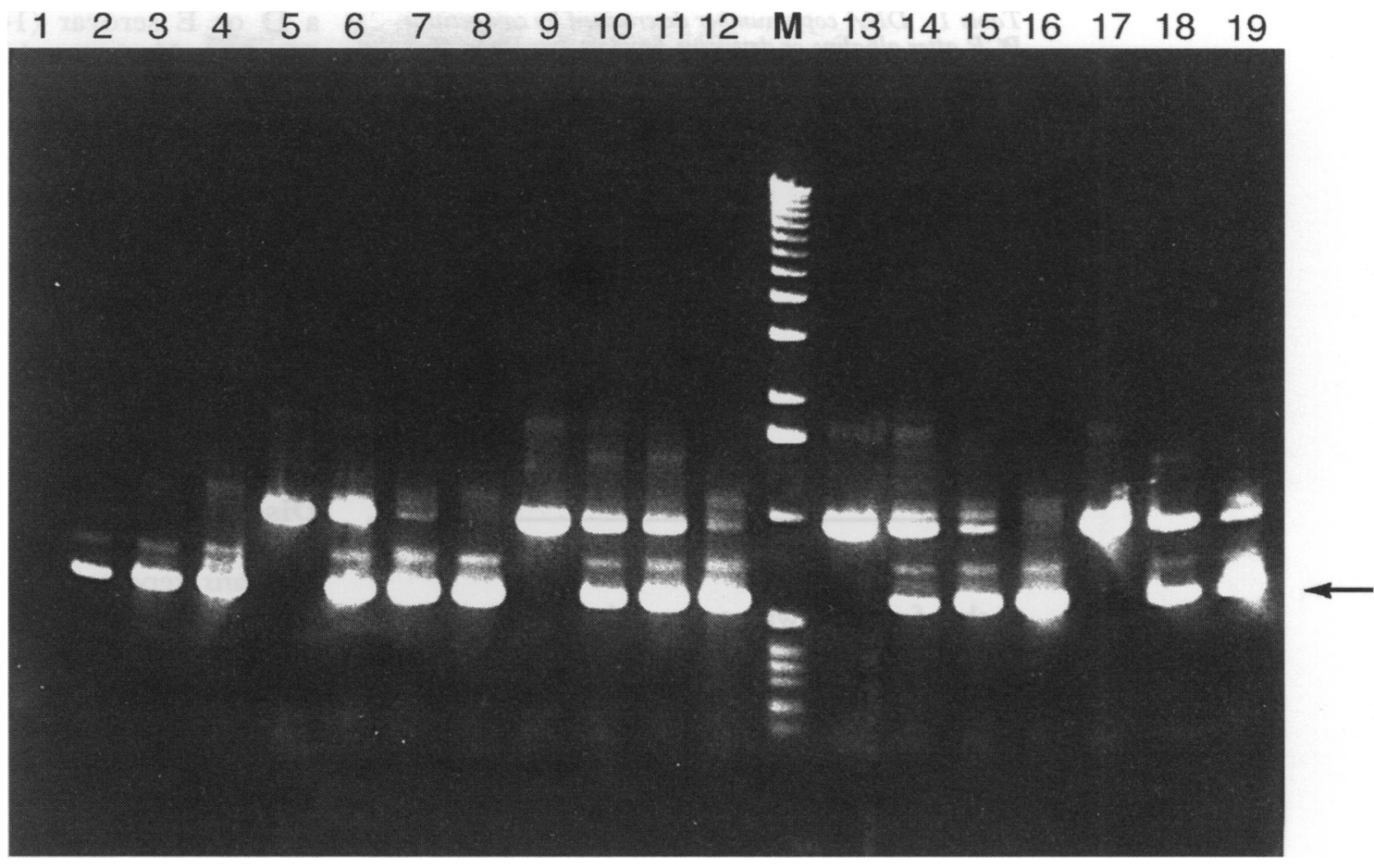

Figure 1 Titration of $C$ trachomatis MOMP gene sequences by competitive PCR. Mixtures containing $5 \mu l$ of a 1:100 dilution of sample DNA and either $0,10,100$ or 1000 copies of control $D N A$ were amplified by nested PCR and $10 \mu l$ aliquots analysed by agarose gel electrophoresis. The first 4 lanes contained a negative control rather than sample DNA (the first lane with 0 copies of control DNA has no bands); followed by 4 lanes for patient 1; 4 lanes for patient 2; a molecular weight ladder; 4 lanes for patient 3 and 3 lanes for patient 4. An arrow at the right side of the ethidium bromide stained gel indicates the position of the control DNA at about $600 \mathrm{bp}$. From lanes 6 and 7 , visual inspection indicated that patient 1 had about 8 copies of $C$ trachomatis DNA as it had slightly less than the 10 copy control in lane 6 and considerably less than the 100 copy control in lane 7 . In lane 11 the upper band of patient DNA is about $40 \%$ as intense as the lower band containing 100 copies indicating about 40 copies. For patient 3, lane 14 indicates patient DNA equivalent to the 10 copy control which is confirmed in lane 15 where patient DNA represents only about $10 \%$ of the 100 copy control. Patient 4 sample revealed about 20\% of the amount of the 100 copy control (lane 19) and slightly more $D N A$ than the 10 copy control (lane 18) indicating approximately 20 copies. These values would be multiplied by the appropriate dilution factor to obtain a copy number per $0.3 \mathrm{ml}$

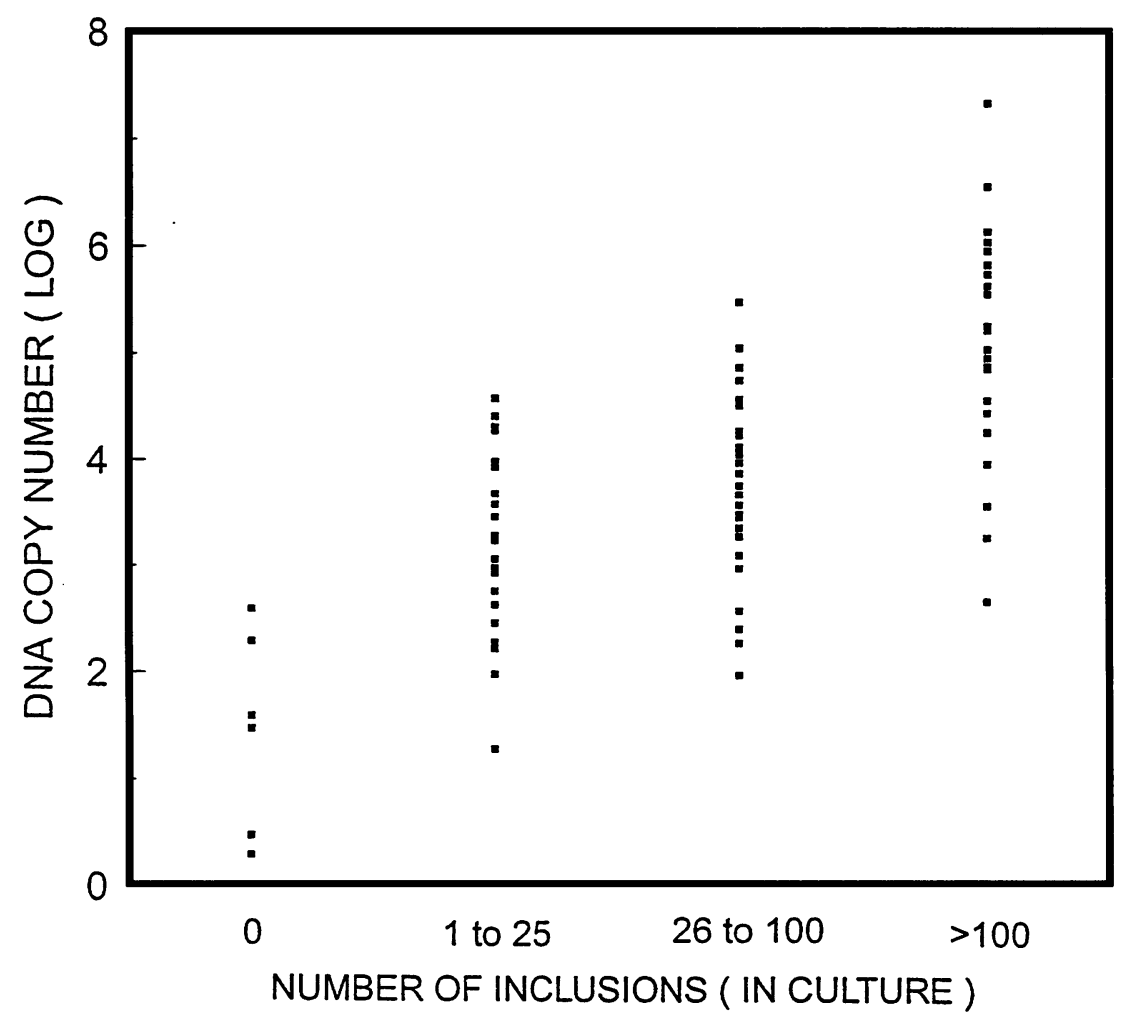

Figure 2 Correlation between number of $C$ trachomatis inclusions observed in culture and number of copies of $C$ trachomatis MOMP gene sequence determined by competitive PCR for 111 clinical specimens.
26-100 inclusions $(n=37)$ contained 31,000 copies, while those with fewer than 25 inclusions $(n=30)$ still contained an average of 5,200 copies of the chlamydial MOMP gene. The six samples available that were negative on culture but had yielded positive results with identical serovar identification on two separate PCR amplifications were found to contain an average of only 113 DNA copies and two of these samples had too little DNA to be detected after the tenfold dilution necessary to perform the analysis. From the samples with less than 25 inclusions or 26-100 inclusions the DNA copy number per inclusion was approximately 402 and 496 respectively.

The simple, alkali DNA extraction procedure was compared with detergent-proteinase $\mathrm{K}$ extraction of chlamydial DNA by analysing 12 clinical samples with both methods and then quantitating the chlamydial DNA released (table 1). For 11 of the 12 samples greater amounts of chlamydial DNA were detected when the detergent-proteinase $K$ procedure was employed.

Reproducibility of $C$ trachomatis quantitation procedures

A clinical sample was divided into 10 aliquots, 
Table 1 DNA copy number determined by competitive $P C R$ after alkaline or detergent-protease extraction of Chlamydia trachomatis $D N A$

\begin{tabular}{rcc}
\hline & \multicolumn{2}{l}{ DNA copy number } \\
\cline { 2 - 3 } Specimen & $\begin{array}{l}\text { Alkaline } \\
\text { extraction }\end{array}$ & $\begin{array}{l}\text { Detergent-protease } \\
\text { extraction }\end{array}$ \\
\hline $27 \mathrm{Ur}$ & 20000 & 60000 \\
$30 \mathrm{Cx}$ & 4000 & 34000 \\
$225 \mathrm{Ur}$ & 6000 & 24000 \\
$2944 \mathrm{Cx}$ & 16000 & 60000 \\
$2967 \mathrm{Ur}$ & 600 & 6000 \\
$2968 \mathrm{Cx}$ & 160000 & 420000 \\
$3013 \mathrm{Cx}$ & 4000 & 6000 \\
$3039 \mathrm{Cx}$ & 800 & 6000 \\
$3136 \mathrm{Cx}$ & 200 & 3000 \\
$3159 \mathrm{Ur}$ & 900 & 9000 \\
$3185 \mathrm{Ur}$ & 1075 & 30000 \\
$3270 \mathrm{Cx}$ & 35000 & 30000 \\
\hline
\end{tabular}

each of which was separately extracted with the detergent-proteinase $K$ procedure and quantitated by PCR. The sample revealed an average of 34,000 molecules and a standard deviation of $\pm 17,800$ indicating a coefficient of variation of $52 \cdot 3 \%$.

On 10 separate occasions the number of inclusions observed in cells infected with the low inclusion count specimen (see Materials and methods) were counted by one of us (EF). An average of 41.6 (SD 19.6) inclusions were noted indicating a coefficient of variation of $47 \cdot 1 \%$.

Each of 10 aliquots of a clinical sample was separately prepared and stained with fluorescein-labelled anti- $C$ trachomatis monoclonal antibodies. The average number of particles counted by one of us (EF) was 378 (SD 180) with a coefficient of variation of $47 \cdot 8 \%$.

\section{Comparison of quantitation procedures}

DNA molecules, particles and infectious units were quantitated in clinical samples from 12 patients (table 2). On average, 595 DNA molecules and 87 particles could be counted per inclusion-forming-unit (ifu). The ratio of particles per ifu was slightly higher in samples with less than 100 inclusions than in those with more inclusions (135, SD 111 versus 21, SD 10). Samples with a "C" group serovar (Ia, J or $\mathrm{K}$ ) showed a tendency towards a higher ratio of particles per ifu than those with

Table 2 Quantitation of DNA molecules, particles and inclusion-forming-units from 12 clinical specimens

\begin{tabular}{|c|c|c|c|c|c|}
\hline \multirow{2}{*}{$\begin{array}{l}\text { Specimen } \\
\text { No }\end{array}$} & \multirow[b]{2}{*}{ Serovar } & \multirow{2}{*}{$\begin{array}{l}\text { Number of } \\
\text { inclusions* }\end{array}$} & \multicolumn{3}{|l|}{ Ratio * } \\
\hline & & & Particles/ifu & DNA/ifu & DNA/particle \\
\hline $\begin{array}{r}27 \mathrm{Ur} \\
30 \mathrm{Cx} \\
225 \mathrm{Ur} \\
2944 \mathrm{Cx} \\
2967 \mathrm{Ur} \\
2968 \mathrm{Cx} \\
3013 \mathrm{Cx} \\
3039 \mathrm{Cx} \\
3136 \mathrm{Cx} \\
3159 \mathrm{Ur} \\
3185 \mathrm{Ur} \\
3270 \mathrm{Cx} \\
\text { Average } \\
\text { Median }\end{array}$ & $\begin{array}{l}\text { D } \\
\text { Ia } \\
\text { E } \\
\text { E } \\
\text { J } \\
\text { J } \\
\mathbf{E} \\
\mathbf{F} \\
\mathbf{F} \\
\mathbf{F} \\
\mathbf{K} \\
\mathbf{E}\end{array}$ & $\begin{array}{r}132 \\
32 \\
128 \\
33 \\
19 \\
268 \\
38 \\
12 \\
70 \\
12 \\
147 \\
388 \\
107 \\
54\end{array}$ & $\begin{array}{r}24 \\
263 \\
23 \\
84 \\
279 \\
35 \\
30 \\
204 \\
60 \\
22 \\
11 \\
11 \\
87 \\
32.5\end{array}$ & $\begin{array}{r}455 \\
1063 \\
188 \\
1818 \\
316 \\
1567 \\
158 \\
500 \\
43 \\
750 \\
204 \\
77 \\
595 \\
385\end{array}$ & $\begin{array}{c}19 \\
4 \\
8 \\
22 \\
1 \cdot 1 \\
45 \\
5 \\
2 \cdot 5 \\
0 \cdot 7 \\
34 \\
19 \\
7 \\
14 \\
7 \cdot 5\end{array}$ \\
\hline
\end{tabular}

*The total number of inclusions per coverslip (ifu) was counted following infection with $0.3 \mathrm{ml}$ of sample. Particles were counted by direct immunofluorescence after pelleting $10 \mu \mathrm{l}$ or $100 \mu \mathrm{l}$
aliquots of sample. DNA molecules were quantitated by competitive PCR from dilutions of the original sample. After adjusting all quantities to $0.3 \mathrm{ml}$ of original sample, ratios were calculated by division. a D or E serovar (147, SD 138 versus 34, SD 29). Variation in the number of DNA molecules per ifu or per particle could not be correlated with serovar or number of ifu. Considerable variation was noted in the ratios of particle per ifu, DNA molecules per ifu and DNA molecules per particle (coefficient of variation $\geqslant 100 \%$ ) among the 12 specimens. The difference in these ratios observed between sexual partners $2967 \mathrm{Ur}$ and $2968 \mathrm{Cx}$ was particularly high even though they harboured $C$ trachomatis of the same serovar.

\section{Discussion}

The competitive PCR procedure for $C$ trachomatis reported here gave a sensitive and reproducible assessment of the number of molecules of $C$ trachomatis DNA in clinical samples when compared with counting inclusions produced in infected cells or particles stained by immunofluorescence. The sensitivity of culture for detection of $C$ trachomatis was found to be approximately one inclusion for 595 DNA molecules. As there is only one copy of the MOMP gene per chromosome and probably only one chromosome per elementary body this would translate to a particle to infectious unit ratio similar to many eukaryotic viruses. The culture procedure we employed was similar to that used by many clinical laboratories but was not optimally sensitive in that specimens were usually frozen once at $-70^{\circ} \mathrm{C}$ prior to culture and blind passage was not undertaken. ${ }^{18}$ It would not have been feasible, however, to quantitate $C$ trachomatis by culture after blind passage as it would have required using multiple dilutions at the primary isolation step.

The deviation from one of the particle to ifu, DNA to ifu or DNA to particle ratio indicated that loss of infectivity and antigenicity occurred in the sample. As the coefficient of variation was higher among the 12 separate specimens than in an individual specimen tested 10 times, it could be concluded that loss of infectivity and antigenicity was variable among specimens. The composition of the specimen itself must have been an important factor in this loss of infectivity and antigenicity because samples taken from sexual partners carrying the same $C$ trachomatis serovar and transported simultaneously displayed among the most widely variable particle to ifu, DNA to ifu and DNA to particle ratios of all 12 specimens.

We observed a higher particle to infectious unit ratio than would be predicted from direct immunofluorescent observation of $C$ trachomatis elementary bodies. Indeed culture has been shown to be at least as sensitive as direct immunofluorescence even when samples with only 1-5 immunofluorescent particles were considered positive. ${ }^{1920}$ Although this could be interpreted to imply that culture will be positive if the sample contains 1 to 5 elementary bodies, it is not clear that chlamydial particles can be as efficiently transferred from a swab to a glass slide for direct immunofluorescence as they can be released into $2 \mathrm{SP}$ 
medium for culture. It would be expected, however, that chlamydial particles in solution would be efficiently transferred to a glass slide by drying and fixing. Indeed, a recent evaluation of the sensitivity of $C$ trachomatis detection procedures that also prepared MicroTrak direct immunofluorescence slides by pelleting chlamydia from transport media rather than by direct application from a swab also concluded that MicroTrak was as sensitive as PCR detection and considerably more sensitive than enzymatic assays. ${ }^{21}$ Other authors have also reported that immunofluorescentstaining particles can frequently be detected in 2SP medium from PCR-positive, culturenegative specimens. ${ }^{69}$

We have identified two approaches for the routine quantitation of $C$ trachomatis. In laboratories employing PCR, competitive PCR will yield reproducible and sensitive results if a modified template is employed such as that described here. Virtually any clinical laboratory could count immunofluorescent particles usually in the same clinical sample employed for another procedure. This would require centrifuging the sample in a microfuge in order to remove sample buffer components (such as sucrose or detergents) that would interfere with the binding of chlamydia particles to a glass slide. Indeed this simple procedure performed routinely on samples considered weak positive by antigen detection, culture or PCR would not only serve to confirm that they are indeed positive, but would also monitor the sensitivity of the detection procedure routinely employed.

The authors thank Monique Lemieux and Nicole Blais for manuscript preparation. This work was supported by grant 94 ER 2055 of the Fonds pour la Formation de Chercheurs et l'Aide à la Recherche.

1 Schachter J. Rapid diagnosis of sexually transmitted diseases-speed has a price. Diagn Microbiol Infect Dis 1986;4:185-9.

2 Mahony JB, Chernesky MA. Effect of swab type and storage temperature on the isolation of Chlamydia trachomatis from clinical specimens. F Clin Microbiol 1985;22:865-7.

3 Jones RB, van der Pol B, Katz BP. Effect of differences in specimen processing and passage technique on recovery of Chlamydia trachomatis. $f$ Clin Microbiol 1989;27: 894-8.

4 Mahony JB, Luinstra KE, Jang D, Sellors J, Chernesky MA. Chlamydia trachomatis confirmatory testing of PCR-positive genitourinary specimens using a second set of plasmid primers. Molec Cell Probes 1992;6:381-8.

5 Ossewaarde JM, Rieffe M, Rozenberg-Arska M, Ossenkoppele PM, Nawrocki RP, van Loon AM. Ossenkoppele PM, Nawrocki RP, van Loon AM. chain reaction test for detection of Chlamydia trachomatis. chain reaction test for detection of

6 Ostergaard L, Birkelund S, Christiansen G. Use of polymerase chain reaction for detection of Chlamydic trachomatis. F Clin Microbiol 1990;28:1254-60.

7 Frost EH, Deslandes S, Bourgaux-Ramoisy D. Sensitive detection and typing of Chlamydia trachomatis using nested polymerase chain reaction. Genitourin Med 1993; 69:290-4.

8 Loeffelholz MJ, Lewinski CA, Silver SR, et al. Detection of Chlamydia trachomatis in endocervical specimens by polymerase chain reaction. $\mathcal{F}$ Clin Microbiol 1992;30: polymerase

9 Jaschek G, Gaydos CA, Welsh LE, Quinn TC. Direct detection of Chlamydia trachomatis in urine specimens from symptomatic and asymptomatic men by using a rapid polymerase chain reaction. $f$ Clin Microbio 1993;31:1209-12.

10 Dille BJ, Butzen CC, Birkenmeyer LG. Amplification of Chlamydia trachomatis DNA by ligase chain reaction. f Clin Microbiol 1993;31:729-31.

11 Becker-André $M$, Hahlbrock K. Absolute mRNA quantification using the polymerase chain reaction (PCR). A novel approach by a PCR aided transcript titration assay (PATTY). Nucl Ac Res 1989;17:9437-46.

12 Gilliland G, Perrin S, Blanchard K, Bunn HF. Analysis of cytokine mRNA and DNA: detection and quantitation by competitive polymerase chain reaction. Proc Natl by competitive polymerase chai

13 Stephens RS, Sanchez-Pescador R, Wagar EA, Inouye C, Urdea MS. Diversity of Chlamydia trachomatis majo outer membrane protein genes. $\mathcal{F}$ Bacteriol 1987;169: 3879-85.

14 Sambrook J, Fritsch EF, Maniatis T. Molecular cloning: Laboratory Manual. Cold Spring Harbor, NY: Cold Spring Harbor Laboratory Press 1989.

15 Armitage P, Berry G. Statistical Methods in Medical Research. 2nd ed. Oxford, England: Blackwell Scientific Publications, 1987.

16 Frost EH, Deslandes S, Bourgaux-Ramoisy D. Chlamydia trachomatis serovars in $\mathbf{4 3 5}$ urogenital specimens typed trachomatis serovars in 435 urogenital specimens typed f Infect Dis 1993;168:497-501.

17 Datta $\mathrm{P}$, Frost E, Peeling R, et al. Ophthalmia neonatorum in a trachoma endemic area. Sex Transm Dis 1994;21: $1-4$

18 Schachter J, Martin DH. Failure of multiple passages to increase chlamydial recovery. $f$ Clin Microbiol 1987;25: 1851-3.

19 Forbes BA, Bartholoma N, McMillan J, et al. Evaluation of a monoclonal antibody test to detect chlamydia in cervical and urethral specimens. F Clin Microbiol 1986;23. 1136-7.

20 Hipp SS, Han Y, Murphy D. Assessment of enzyme immunoassay and immunofluorescence tests for detection of Chlamydia trachomatis. $¥$ Clin Microbiol 1987;25: $1938-43$.

21 Thomas BJ, MacLeod EJ, Taylor-Robinson D. Evaluation of the sensitivity of 10 diagnostic assays for Chlamydia trachomatis by use of a sample laboratory procedure. $\ngtr$ Clin Pathol 1993;46:408-10. 